Meta

Journal des traducteurs

Translators' Journal

\title{
Physiology: a Questionnaire
}

\section{Sylvie-Michelle Lambert et Wallace Earl Lambert}

Volume 30, numéro 1, mars 1985

Interprétation de conférence

URI : https://id.erudit.org/iderudit/003381ar

DOI : https://doi.org/10.7202/003381ar

Aller au sommaire du numéro

Éditeur(s)

Les Presses de l'Université de Montréal

ISSN

0026-0452 (imprimé)

1492-1421 (numérique)

Découvrir la revue

Citer ce document

Lambert, S.-M. \& Lambert, W. E. (1985). Physiology: a Questionnaire. Meta,

30(1), 68-72. https://doi.org/10.7202/003381ar d'utilisation que vous pouvez consulter en ligne.

https://apropos.erudit.org/fr/usagers/politique-dutilisation/ 


\section{PHYSIOLOGY : A QUESTIONNAIRE}

Cognitive psychologists are somewhat intrigued by the fact that people, whether they be right - or left-handed, may pick up a ringing telephone with one hand or the other, then place the receiver on their 'preferred' ear.

Most of us do this automatically, without thinking, although if we have to take notes while conversing on the phone, we may have to 'cradle' the phone on one ear or the other in order to be able to write, or we may simply hold the phone with the hand that is free.

In order to determine just how right - or left-handed you are, you will find a short questionnaire called the Edinburgh Inventory of Handedness appended hereto which only requires a few minutes to complete.

Where you, the interpreter, come in is even more interesting. Most interpreters who have been working for many years claim that they often like to move one of the ear phones slightly off one ear. Several reasons are given for this phenomenon ; for example, the fact that the headphones are too tight or that the interpreter prefers or needs to hear the sound of his or her own voice. It could also be related to the telephone ear in that we simply prefer one ear or pay better attention (process incoming information more deeply) when listening with our 'preferred' ear. Remember that booth conditions are not always ideal and that if there are two interpreters in the same booth, at times, an interpreter may choose to keep both headphones firmly on both ears simply to block out all external stimuli.

We would be very grateful for your help in this research. What we ask is that you answer the following questions, taking time in doing so and thinking carefully about it before answering. Feel free to take this questionnaire home and fill it in at your convenience. If so, kindly leave the completed questionnaire in my pigeon hole at the Institute.

SYLVIE-MICHÈLE LAMBERT WALLACE EARL LAMBERT

1. Do you keep both headphones on both ears during simultaneous interpretation?

(Assuming that booth conditions are ideal in that you are alone in the booth or that there is no need to block out interference from adjoining booths, etc.)

Yes. No 
If the answer is YES, why do you keep both headphones on?

2. If you remove one headphone, which one do you remove? I usually try to free my LEFT ear.

I usually try to free my RIGHT ear.

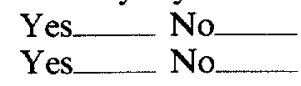

Why do you feel to have that ear free?

3. What percentage of the time is that ear (left or right) uncovered, approximately?

What factors affect your tendency to free one ear?

For example : tiredness?

$$
\begin{aligned}
& \text { difficulty of the material being interpreted? } \\
& \text { pain due to heavy headsets? }
\end{aligned}
$$

Please list other possible reasons :

4. Dos the language direction you are working into come into play? For example, when interpreting from $B$ to $A$, will you remove your headphone from one ear whereas when working from A to B you will not ? or viceversa? In other words, does the language direction have any effect on your headphone removal?

$$
\text { Yes___. No N }
$$

Please explain if YES :

5. What is your mother-tongue?

What is your A language?

What is your $B$ language?

What is your $\mathrm{C}$ language?

6. Are you left- or right-handed ?

Left-handed

Right-handed

(Bearing in mind that a more thorough handedness questionnaire is included further on.)

7. When your telephone is ringing, which hand do you normally use to pick up the receiver? Pretend that the phone is a wall phone and that the receiver is centered in the middle of the phone, which hand would you use then?

$$
\text { Left__ Right }
$$

8. Once you have picked up the receiver, which ear do you now place it on ?

$$
\text { Left Right }
$$

9. If someone is giving you instructions over the phone and you are writing them down, what do you do with the receiver to be able to take notes and listen at the same time? 
10. Suppose you are listening to a casual conversation with the receiver placed on one or the other ear, do you have to switch to the other ear in order to write something down with your preferred hand?

Yes No

11. Do you ever 'cradle' the receiver between your cheek and your neck when you are taking notes and speaking on the phone at the same time?

Yes No

If YES, which ear do you cradle?

Left__ Right

12. Have you ever picked up a ringing telephone, placed it on your 'non-preferred' ear (for whatever reason) and then suddenly decide to switch it over to your 'preferred' ear because you felt you weren't hearing well enough or processing deeply enough with your 'non-preferred' ear?

$$
\text { Yes___ No_ }
$$

Could you please describe an instance of this occurrence?

13. Which is your 'preferred' ear (for the telephone, for interpreting, for just listening in general, or when you 'cock' your ear) :

for the telephone :

Left___ Right

for interpreting :

Left__ Right

when listening in general :

Left__ Right

when 'cocking' your ear :

Left__ Right

when listening to whispering :

Left___ Right

when listening to popular music :

Left__ Right

14. Which side of your face (including your ears) do you think is the most attractive?

My left side My right side No difference

15. For you, which side of the brain seems to be more active for the following activities?

- listening to popular music?

$\begin{array}{ll}\text { Left___ Right___ } & \text { Right___ } \\ \text { Left___ } & \text { Right___ } \\ \text { Left__ } & \text { Right } \\ \text { Left__ } & \text { Right___ } \\ \text { Left__ } & \text { Right }\end{array}$

- listening to classical music ?

- listening to a friend talk ?

- listening to lectures?

- listening to the radio?

Left Right 
16. Some vital statistics :

Name : (optional, but I don't want to hand this questionnaire to the same person twice)

Age :

Sex :

Number of years as a simultaneous interpreter :

(students are included)

Do you have any visual or hearing impairment that you know of?

Please describe :

17. Assuming that your mother-tongue is given a score of 4 , can you rate your degree of bilinguality for your other languages and the age at which you acquired them? Please list the languages.

\section{READ WRITE SPEAK UNDERSTAND \\ $\begin{array}{lllll}\text { Mother-tongue } & 4 & 4 & 4 & 4\end{array}$}
A language
$B$ language
C language

age :

age :

age :

\section{EDINBURGH INVENTORY OF HANDEDNESS}

Please indicate the hand or the foot you use when :

right left

1. Brushing your hair

2. Brushing your teeth

3. Writing

4. Cutting with a knife

5. Eating with a fork or spoon

6. Throwing a ball

7. Drawing a picture

8. Cutting with scissors

9. Sweeping with a broom (which hand is on top ?)

10. Striking a match (which hand holds the match ?)

11. The foot you kick with 
12. Eye used to look inside a telescope

Handedness in your family

Mother:

Right

Left

Father :

Brother(s) :

Sister(s) :

Children :
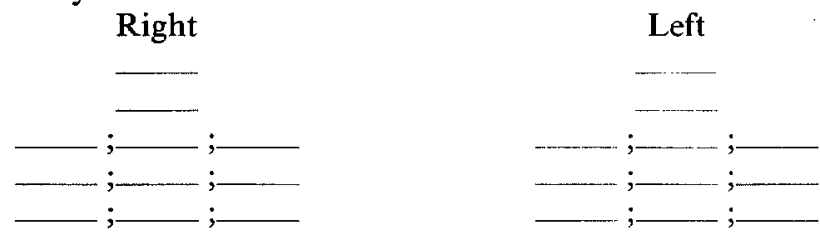

Thank you

If you have any questions, kindly contact me on (408) 373-6783 or Dr. W.E. Lambert on (514) days : 392-4886, evenings : 735-2068. 